\title{
Modernleşme Teorisini Yeniden Düşünmek: Ekonomik Kalkınma ve Demokrasi İlişkisine Eleştirel Bir Bakış
}

\author{
DOI: 10.26466/opus.561066 \\ * \\ Șebnem Yardımcı Geyikçi* - Uğur Çil ${ }^{* *}$ \\ * Dr. Öğretim Üyesi, Hacettepe Üniversitesi, İ̈BF, Beytepe/Ankara/Türkiye \\ E-Posta: sebnemgeyikci@hacettepe.edu.tr ORCID: 0000-0001-6444-5920 \\ ** Yüksek Lisans Öğrencisi, Hacettepe Üniversitesi, İïBF, Beytepe/Ankara/Türkiye \\ E-Posta: ugur.cil@yandex.com \\ ORCID: $\underline{0000-0002-4550-5550}$
}

Öz

1960'larda toplumların modern ekonomik gelişme aşamasına ulaşması için kültürel ve toplumsal bir değiş̧im sürecine ihtiyaç duyduğundan yola çıkan modernleşme teorisi, Batı dışı toplumlarda geri kalmışlı̆̆ının anlaşılması, açıklanması ve bu toplumların gelişme pratiklerine katkı să̆lanması amacıyla sosyoloji ve siyaset biliminin de konusu haline gelmiştir. Modernleşme teorisi "Karşılaştırmalı Siyaset" içinde de özellikle demokrasinin bir yönetim biçimi olarak baskın hale gelmesiyle önemli bir yaklaşım olarak kendini göstermiştir. Dolayısıyla modernleşme teorisinin demokratikleşme süreçlerinin anlaşılması ve sebep-sonuç ilişkisinin tanımlanması, anlamlandırılması ve açıklanması konularında oldukça sık başvurulan bir yaklaşım olduğu söylenebilir. Karşılaştırmalı siyaset içinde modernleşme teorisinin kurucusu kabul edilen Seymour Martin Lipset demokratikleşmeyi neredeyse doğal kabul edilen değiş̧im sürecinin bir parçası olarak görür ve ekonomik gelişmişliğin beraberinde sosyal ve siyasal gelişmişliği de getirdiğini iddia eder. Lipset'in 1959 yılında yazdı̆̆g "Demokrasinin Toplumsal Gereklilikleri: Ekonomik Kalkınma ve Siyasal Meşruiyet" (Some Social Requisites of Democracy: Economic Development and Political Legitimacy) başlıklı makalesi öncül çalışma niteliğindedir. Lipset makalesinde demokrasi ve ekonomik gelişmişlik arasında var olduğunu iddia ettiği korelasyon üzerine kurguladı̆̆ hipotezinde, bir ulusun ekonomik gelişmeye bağlı olan refah seviyesi arttıkça, o toplum içinde demokrasinin de o derece sürdürülebilir olacağını savunmuştur. Bu makalenin amacı karşılaştırmalı siyaset bilimi çerçevesinde modernleşme teorisini yeniden düşünmektir. Bu kapsamda, Lipset'in yukarıda adı geçen makalesi merkeze alınarak, modernleşme teorisi bağlamında demokratikleşme süreçleri üzerine yapılan okumalar eleştirel bir biçimde ele alınacaktır.

Anahtar Kelimeler: Demokrasi, Demokratikleşme, Modernleşme Teorisi, Seymour Martin Lipset, Ekonomik Kalkınma 


\title{
Rethinking Modernization Theory: A Critical Perspective on The Relationship Between Economic Development and Democracy
}

\begin{abstract}
In the 1960s modernization theory has become one of the dominant paradigms in sociology and political science and both disciplines relied on it in explaining why non-Western countries remained underdeveloped. Modernization theory, which suggests that economic development requires a cultural and social transformation, has also affected the literature on comparative politics, particularly when democracy has become the dominant regime type in the Western world. As such, many studies to date has employed this approach as a way to understand and explain the processes of democratization in different contexts. Seymour Martin Lipset, the founding father of modernization theory, approaches democratization as a natural outcome of modernization and forms a linear relationship between the economic development and the social and political development. Lipset's article "Some Social Requisites of Democracy: Economic Development and Political Legitimacy" published in 1959 is considered to be a seminal work in this respect. Lipset argues that there is a correlation between economic development and democracy in that the higher the level of economic development and economic welfare the higher the chances of democracy to survive. The major goal of this article is to rethink the premises of modernization theory based on the aforementioned article of Lipset from the perspective of comparative politics. Accordingly, in this paper we will critically analyse the theories of democratization based on the modernization approach and try to observe the impact of modernization theory on the democratization literature.
\end{abstract}

Keywords: Democracy, Democratization, Modernization Theory, Seymour Martin Lipset, Economic Development 


\section{Giriş}

Demokrasi, merkezinde tarihi, siyasi, sosyal ve kültürel olarak Avrupa'nın bulunduğu ve bugün $A B D$, Kanada ve Avustralya gibi ülkeleri de kapsayan Batı dünyasını tanımlayan ve şekillendiren hatta bazı yönleriyle onu dünyanın geri kalanından ayıran en önemli kavramlardandır. Batı dünyası, demokrasi olgusunun bir ideal olarak ortaya çıktığı antik Yunan medeniyetinden günümüze uzanan 24 asırlık tarihi içerisinden süzülerek yeniden şekillendiği bir yer haline gelmiştir.

Özellikle Avrupa'daki siyasal düzlemi tanımlayan feodalizm ve monarşinin giderek zayıflamasıyla eş zamanlı olarak ortaya çıkan "merkantilizm" yani bir devletin refahının sahip olduğu ekonomik güç ve birikim üzerinden belirlenmesi, bu süreci başlatan faktörlerdendir. Benzer bir şekilde yine aynı dönemde Avrupa ülkeleri arasında adeta bir hammadde ve pazar yaratma yarışı haline gelen "kolonyalizm" siyasal yapılanma ve idareden sosyal yaşama, kültürden şehirleşmeye kadar uzanan geniş bir yelpaze içerisinde Avrupa devletlerini ve toplumlarını dönüştürmeye başlamıştır. Bütün bu değişimlerin liberal siyasal düşüncenin ortaya çıkışından Fransız Devrimi'ne ve nihayetinde de demokrasiye uzanan çok boyutlu siyasal ve sosyal transformasyonu tetikleyen önemli dönüm noktaları olduğu söylenebilir.

Oldukça yüzeysel olarak değinilen bu vakalar ve olgular silsilesi, Batı dünyasının günümüzde demokrasinin, demokrasinin temelini oluşturan düşüncelerin ve demokrasiyi mümkün kılan siyasi, sosyal ve kültürel dinamiklerin merkezi haline gelmesinin tek bir düzleme indirgenemeyeceğini göstermektedir. Dolayısıyla demokrasinin çok boyutlu ve kompleks bir fenomen olarak birçok disiplin tarafından ele alınmasının ve okunmasının oldukça tutarlı bir yaklaşım ve anlayış biçimi olduğu belirtilebilir.

Bu bağlam içinde 17. yüzyıldan başlayarak Avrupa'da yaşanan düşünsel ve bilimsel aydınlanmanın bir sonucu olarak görülebilecek endüstriyel gelişmeler ile üretimin artması, bunun sonucunda da özel mülkiyet olgusunun gelişerek, merkantilizmden kapitalizme geçişin sağlanmasıyla "modernleşme" olgusu neredeyse bütün dünyayı etkisi altına alan bir gerçeklik olmuştur. Öyle ki zaman içerisinde Batı dünyasını da aşarak adeta küresel bir "logos" haline gelmiştir. Modernleşme olgusu 2. Dünya Savaş1 
sonrasında Batı dünyasının model olarak alınmasıyla tüm dünya toplumlarının modernleşebileceğini varsayan bir toplumsal değişim yaklaşımı olarak "modernleşme teorisi" ne dönüşmüştür (Altun, 2002, s.26).

Toplumların modern ekonomik gelişme aşamasına ulaşması için kültürel ve toplumsal bir değişim sürecine ihtiyaç duyduğundan yola çıkan modernleşme teorisi (a.g.e, s.26), gelişmenin öncelikle ekonomik bir problem olarak tanımlandığı iktisat bilimi tarafından ele alınmıştır. Daha sonrasında ise Batı dışı toplumlarda geri kalmışlığının anlaşılması, açıklanması ve bu toplumların gelişme pratiklerine katkı sağlanması amacıyla sosyoloji ve siyaset biliminin de konusu haline gelmiştir (a.g.e, s.62).

Modernleşme teorisi "Karşılaştırmalı Siyaset" içinde de özellikle demokrasinin bir yönetim biçimi olarak baskın hale gelmesiyle önemli bir yaklaşım olarak kendini göstermiştir. Dolayısıyla modernleşme teorisinin demokratikleşme süreçlerinin anlaşılması ve sebep-sonuç ilişkisinin tanımlanması, anlamlandırılması ve açıklanması konularında oldukça sık başvurulan bir yaklaşım olduğu söylenebilir. Modernleşme teorisi, demokrasiyi tarım odaklı, feodal ve geleneksel toplumlardan, kapitalist, sanayileşmiş, rasyonelleşmiş ve ulus-devlet çerçevesinde örgütlenmiş toplum türüne geçiş olarak tanımlayan "modernite" kavramının bir parçası olarak algılamakta ve bu tür bir geçiş yoluyla ortaya çıkan değişikliklerin her ülkede er ya da geç yaşanacağını varsaymaktadır (Gürsoy, 2016, s.87).

Karşılaştırmalı siyaset içinde modernleşme teorisinin kurucusu kabul edilen Seymour Martin Lipset de bu varsayımlardan yola çıkarak demokratikleşmeyi neredeyse doğal kabul edilen değişim sürecinin bir parçası olarak görür ve ekonomik gelişmişliğin beraberinde sosyal ve siyasal gelişmişliği de getirdiğini iddia eder (a.g.e, s.87). Bu çerçevede, Lipset'in 1959 yılında yazdığ 1 "Demokrasinin Toplumsal Gereklilikleri: Ekonomik Kalkınma ve Siyasal Meşruiyet" (Some Social Requisites of Democracy: Economic Development and Political Legitimacy) başlıklı makalesi öncül çalışma niteliğindedir. Lipset makalesinde demokrasi ve ekonomik gelişmişlik arasında var olduğunu iddia ettiği korelasyon üzerine kurguladığ hipotezinde, bir ulusun ekonomik gelişmeye bağlı olan refah seviyesi arttıkça, o toplum içinde demokrasinin de o derece sürdürülebilir olacağını savunmuştur (Lipset, 1959, s.75). 
Bu makalenin amacı karşılaştırmalı siyaset bilimi çerçevesinde modernleşme teorisini yeniden düşünmektir. Bu kapsamda, Lipset'in yukarıda adı geçen makalesi merkeze alınarak, modernleşme teorisi bağlamında demokratikleşme süreçleri üzerine yapılan okumalar eleştirel bir biçimde ele alınacaktır. Modernleşme teorisinin mümkün olduğunca geniş ve farklı perspektiflere dayanan bir analiz düzlemi üzerinde değerlendirilmesini yapabilmek için bu alanda araştırma yapan kişilere genelden eleştirele uzanan bir perspektif sunulacaktır. Böylelikle konu üzerine sonrasında yapılacak çalışmalara bir alt yapı ve katkı sağlanacaktır.

Bu çerçevede öncelikle "demokrasi" ve "demokratikleşme" kavramlarının karşılaştırmalı siyaset disiplini içinde ele alınış biçimi tanımlanacaktır. Ardından temelini Lipset'in attığı modernleşme teorisinin demokratikleşmeyi ekonomik gelişmişliğin bir sonucu olarak gören ve bu değişim sürecinin her ülkede er ya da geç yaşanacağını varsayan analiz ve araştırmalar genel olarak değerlendirilecektir. Bu yolla modernleşme teorisi üzerinden geliştirilen temel argümanlar, inceleme noktaları, yaklaşımların farklılıkları, zayıf ve güçlü yönleri eleştirel bir bakış ile yansıtılmaya çalışlacaktır.

\section{Karşılaştırmalı Siyasette Demokrasi ve Demokratikleşme}

İçinde bulunduğumuz 21. yüzyılı siyasi, sosyal ve kültürel olarak etkileyen, yön veren ve şekillendiren tüm fikirler ve olgular arasında en önemli olanının demokrasi olduğunu söylemek çok da yanlış olmaz. Demokrasinin özellikle bir yönetim şekli olarak olmasa da içinde barındırdığı özgürlük ve eşitlik gibi evrenselleşmiş kavramları içermesi açısından öncül bir kavram olduğu söylenebilir. Bu kavramların normatif olarak tesir etmediği siyasi, sosyal ya da kültürel bir fikri ya da olguyu bulmanın ise neredeyse imkânsız olduğu reddedilmesi zor olan bir realiteyi tarif etmektedir. Çünkü demokrasi tarihsel gelişim süreci içinde soyut bir kavram olmaktan somut olana evrilirken bir ideal olarak konumlandırdığı özgürlük ve eşitlik kavramlarını maksimize etmek ve bu iki idealin birbiriyle siyasal anlamda kabul edilebilir bir bağdaştırmasını sağlamak amacını taşıyan bir yönetim biçimi olarak tasarlanmıştır (Pennock, 1979, s.149).

Demokrasinin tarihsel bir gelişim süreci içinde meydana geldiği göz önünde bulundurulursa, demokrasinin sabit bir görüngü olmadığ1 yani 
değişken olduğu belirtilmelidir -ve bu nedenle geçmişte demokratik bir pratik olarak tanımlanan olguların günümüzde demokratik olarak görülmeme ihtimali de göz önünde bulundurulmalıdır (Newton ve Van Deth, 2014: 43). Günümüzde demokrasi kavramı oldukça geniş bir kapsam içinde değerlendirilmekte ve siyasi anlamda sembolik gücünün yüksek olması ve birbirinden çok farklı siyasal eylemlerin gerekçelendirilmesinde kullanılmasından dolayı da sosyal bilimler alanında oldukça esnek bir kavram olarak ele alınmaktadır (Sözen, 2016, s.58). Özellikle "demokrasi" kavramının anlamı üzerinde bir uzlaşma olmaması, dünyada var olan demokrasilerin çeşitliliği ve farklılığı, siyasal rejimleri sınıflandırmak için oluşturulan farklı kıstaslar ve kavramlar yoluyla şu ana kadar demokrasinin 550 farklı alt türünün tanımlanmış olması da araştırmacılar açısından oldukça büyük bir engel oluşturmaktadır (Diamond, 1999, s.7).

Siyaset biliminin bir alt disiplini olarak karşılaştırmalı siyaset bilimini meydana getiren ana unsurların başında birbirinden farklı ülke ve kültürlerle ilgilenmesinden ziyade kendi disiplinine ait metotlar yoluyla yaptığı karşılaştırmalarla sosyal fenomenler hakkındaki betimleyici anlatılardan yola çıkarak sosyal bilimlere dayanan açıklamalar geliştirmeyi amaçlaması gelmektedir. Karşılaştırmalı metotların faydalı bir şekilde uygulanabilmesi ve karşılaştırmalı analiz yapılabilmesi için ele alınan konularla alakalı temel kavramların tanımlanması ise bu disiplin içinde oldukça belirleyicidir (Jahn, 2006, s.25). Bu bağlamda "demokrasi" karşılaştırmalı siyaset içinde oldukça geniş tanımlamalara sahip bir kavram olarak ortaya çıkmasına rağmen, özellikle Joseph Schumpeter'in ve Robert Dahl'ın demokrasi kavramları iki temel referans noktası haline gelmiştir. Schumpeter demokratik yönetimi siyasal kararlar vermek için oluşturulmuş bir kurumsal düzenleme olarak konumlandırarak, demokratikliği her yurttaşın oy verebilme ve aday olabilme hakları üzerinden tanımlamış ve bu tanım literatürde "minimalist demokrasi" olarak adlandırılmıştır. Dahl ise demokrasiyi seçimlerin yanı sıra ifade, basın-yayın ve örgütlenme gibi asgari bireysel özgürlüklerle birleştirerek oluşturduğu "poliarşi" ya da diğer bir ifade ile "siyasal demokrasi" kavramı içinde tanımlamıştır. Bu iki tanım arasındaki karşıtlık karşılaştırmalı siyaset disiplini çerçevesinde demokrasinin nasıl tanımlandığını, anlaşıldığını ve ne tür bir düzlem üzerinden ele alındığını ana hatlarıyla ortaya koymaktadır (Sözen, 2016, s.59$60)$. 
Demokrasi kavramına bağlı olmasına rağmen kendine has bir araştırma alanı olarak kabul edilen "demokratikleşme" olgusu ise, bir ülkede düzenli olarak serbest ve adil seçimlerin yapılması, bunun yanında da basın, ifade ve örgütlenme gibi liberal kişisel özgürlüklerin, insan haklarının ve hukukun üstünlügünün kabul edilmesi olarak tanımlanmaktadır. Bu özelliğiyle demokratikleşme demokrasiyi meydana getiren bu pratiklerin hayata geçirildiği bir "süreç" olarak konumlandırılmaktadır. Karşılaştırmalı siyaset, ülkelerin ve toplumların hem demokrasiyle hem de otoriterlikle olan ilişkilerini "otoriterleşme" ile "demokratikleşme" olgularını meydana getiren süreçler arasındaki gel-gitler üzerinden okuyarak, siyasal rejimleri "liberalleşme, geçiş ve konsolidasyon" gibi unsurlar ve göstergeler yoluyla demokratik ya da otoriter olarak önce birbirinden ayırmayı ardından da sınıflandırmayı amaçlamaktadır (Gürsoy, 2016, s.8586). Karşılaştırmalı siyaset disiplini içinde demokratikleşme hakkında yapılan araştırmalarda, demokratikleşmeyi ekonomik gelişmişlik ve kapitalizmin bir sonucu olarak gören "Modernleşme Teorisi" çok fazla eleştirilmesine rağmen hale etkisini korumaktadır.

\section{Lipset ve Modernleşme Teorisi}

Seymour Martin Lipset, 1959 yılında yazdığı, “Demokrasinin Toplumsal Gereklilikleri: Ekonomik Kalkınma ve Siyasal Meşruiyet" başlıklı makalesi ile daha önce belirtildiği üzere ekonomik gelişmişliğin beraberinde siyasi ve sosyal gelişmişliği yani demokratikleşmeyi getirdiği varsayımına ya da öngörüsüne dayanan "modernleşme teorisinin" çerçevesini oluşturmuştur (Goorha, 2012, s.4). Lipset karşılaştırmalı siyaset disiplini içinde demokratikleşme ve ekonomik gelişmişlik arasında kurduğu doğrusal ilişki paradigmasıyla bu alanda yapılan çalışmaları oldukça derinden etkilemiştir ve bu açıdan öncül olarak nitelendirilmektir.

Lipset, makalesinde öncelikle demokratik bir toplumu meydana getiren, istikrarlı, sağlam ve dayanıklı kılan durum ve şartların anlaşılmasının, demokratikleşme süreci olarak tabir edilen yani bir toplumun otoriter bir yönetimden demokrasiye dönüşümü yoluyla ortaya çıkan fenomenin anlaşılması için önemli bir rol oynadığını ileri sürmüştür. Bu bağlamda demokrasiyi destekleyen kurumların ve değerlerin yanı sıra demokrasiyi mümkün kılan kültürel temelin de siyaset bilimi ve sosyoloji disiplinleri 
tarafından demokrasiyi meydana getiren dinamikler olarak kabul gördügünü ifade etmektedir (Lipset, 1959, s.69-70). Özellikle demokrasiyi ve demokratik kurumları meydana getiren toplumsal tutum ve anlayışın özünde Hristiyan-Yahudi temelli Avrupa kültürünün bulunduğunu iddia eden ve demokrasinin bu kültürün bir ürünü olduğunu savunanlara karşı Lipset, Avrupa'da siyasi ve ekonomik gelişmelerin dine dayanmayan bir demokratik düşünceyi doğurduğunu ileri sürmüştür. Özellikle fakirleşme ve sosyal düzensizlik yeni bir uzlaşının ortaya çıkmasında ve bu açıdan ekonomik faktörlerin demokrasiyi meydana getiren dinamikler bağlamında belirleyici bir rol oynadığ tezini öne sürmektedir. (a.g.e, s.70).

Lipset'in demokrasi anlayışı temelde Joseph Schumpeter'in (2003, s.250) ve Max Weber'in (1946, s.226) demokrasi tanımlarının bir sentezi olarak demokrasinin farklılıklar içeren bir toplum içinde siyasal idarecilerin değişimi için yasal firsatlar sunan bir siyasal sistem, toplumun mümkün olduğunca büyük bir kısmına devlet bünyesindeki görevleri üstlenecek kişileri seçmesini sağlayan ve farklı toplumsal çıkar gruplarını karar alma süreçlerine dâhil ederek sorunları çözen bir sosyal mekanizma olduğu fikrine dayanmaktadır (Lipset, 1959, s.70; 1969, s.45). Lipset'e göre bu tür bir demokrasiye geçişi mümkün kılan ya da bu şekilde oluşmuş bir demokrasiyi istikrarlı kılan karmaşık sosyal sistemlerin "ekonomik gelişmişlik" ve "meşruiyet" olmak üzere iki ana ve karakteristik özelliği bulunmaktadır. Bu özellikler Lipset'in demokrasi anlayışı içinde aynı zamanda demokrasiyi ayakta tutan bir toplumu da meydana getirmekte ve tanımlamaktadır (Lipset, 1959, s.71). Lipset bu bağlamda ekonomik gelişmişlik olgusunu "refah, endüstrileşme, şehirleşme ve eğitim" alt başlıklarına ayırarak tanımlarken, aynı zamanda bu kavramların demokrasiye olan etkilerini de ortaya koymaya çalı̧̧maktadır (a.g.e, s.71). Lipset'in bu noktada Weber' in "modern demokrasi sadece kapitalist endüstrileşmenin meydana getirdiği şartlar çerçevesinde ortaya çıkar" tezinden etkilendiğini söylemek yanlış olmayacağı gibi, Lipset'in uzun soluklu siyasal demokrasi geleneğinin bulunmadığı ülkelerin çoğunun da dünyanın az gelişmiş ya da gelişmemiş bölgelerinde bulunduğu argümanını öne çıkararak, ekonomik gelişmişlik ile demokrasi arasında kurduğu doğrusal ilişkiyi temellendirdiğini belirtmek gerekmektedir (a.g.e, s.73).

Her ne kadar bu makale çerçevesinde odak ekonomik gelişmişlik ile demokrasi arasındaki korelasyon üzerinde olsa da, Lipset'in ekonomik 
gelişmişliğin yanı sıra bir ülkenin demokratikleşmesinde önemli bir rol oynayan meşruiyet sorunsalını da siyasal sistem içindeki kurumların doğruluğu ve uygunluğu ile siyasal sistemin etkililiği üzerinden ele alarak demokratikleşmeyle ilişkilendirdiği de unutulmamalıdır (a.g.e, s.71).

\section{Lipset'e Göre Ekonomik Gelişme ve Demokrasi Arasındaki Bağ}

Lipset, ekonomik gelişme ve demokrasi arasındaki ilişki yoluyla çerçevesini oluşturduğu modernleşme teorisinin temelinde Antik Yunan döneminden başlayarak 20. yüzyıla kadar uzanan bir düzlem üzerinde siyasal sistemler ile toplum arasında bir bağ kuran görüşlerden en yaygın ve genel olanının ekonomik gelişme ile demokrasi arasındaki bağlantı olduğunu iddia etmektedir. Yani Lipset'e göre bir toplum ekonomik anlamda ne kadar gelişirse, demokrasinin o toplum içinde var olma ve istikrarlı bir şekilde devam etme şansı da o kadar artırmaktadır (a.g.e, s.75). Lipset'in bu hipotezinin temelinde refah seviyesi yüksek bir toplumun bilinçli bir şeklide siyasal süreçlere etkin olarak katılacağı ve bunun da kendi tabiri ile bir "öz kısıtlama" unsuru oluşturarak, demokrasiye zıt olarak konumlandırılan lafazan siyasetçilerin yanlış eylemlerini engelleyeceği ve bu şekilde de demokrasinin varlığın koruyabileceği öngörüsü bulunmaktadır. Hipotezindeki öngörünün gerçekleşmemesi durumda ise Lipset, ekonomik anlamda gelişmemiş bir toplum içinde siyasal sistemin fakir çoğunluk ile ayrıcalıklı ama azınlık durumundaki elit bir zümrenin arasında kalarak ya yönetimin belli kişilerin elinde olduğu bir oligarşiye ya da diktatörlüğe dayanan bir tahakküm biçimine dönüşeceğini savunmaktadır (a.g.e, s.75).

Lipset, "ekonomik gelişmişlik" olgusunu yüzeysel anlamından öteye taşıyarak daha özellikli bir tanım yapabilmek için bu olguyu meydana getirdiğini savunduğu refah, endüstrileşme, şehirleşme ve eğitim olmak üzere dört alt başlık üzerinden ele almıştır ve bu korelasyonu şu şekilde tanımlamaktadır: "Her ne kadar farklı göstergeler birbirinden ayrı olarak ortaya konmuş olsa da, refah, endüstrileşme, şehirleşme ve eğitim faktörlerinin birbirleriyle bağlantılı olduğu ve beraber ortak bir faktör oluşturdukları oldukça açık. Ve ekonomik gelişmişliğin temelinde bulunan bu faktörler demokrasi ile olan bağlantıyı da beraberinde getirmiştir" (a.g.e, s.80). 
Lipset bu argümandan yola çıkarak, demokrasiyi ve demokrasinin istikrarlı bir şekilde yürütülmesini mümkün kılan faktörlerin tarihi olarak Kuzey Batı Avrupa ve Anglo-Sakson ülkeleri olan ABD ve Avustralya'da yerleşik olduğunu belirtmiştir. Bunun nedeninin ise bu faktörleri meydana getiren kapitalizm temelli ekonomik gelişimin özellikle Protestan inancına sahip bu ülkelerde ortaya çıkarak, demokrasi için bir gereklilik olan ve demokratik gelişim noktasında da bir katalizör görevi gören "yurttaş sınıfını" meydana getirmesi olduğunu ileri sürmüştür (a.g.e, s.85).

Lipset, özet olarak demokrasi ile ekonomik gelişmişlik arasındaki korelasyonu yani birbiri ile doğru orantılı bir yükseliş gösterme halini ya da ilişkisini, özellikle Batı Avrupa ülkeleri ve Latin ülkeleri arasında yaptığ karşılaştırmalarda ortaya çıkan farklar yoluyla belirginleştirerek, gözlemlenmesi ve ortaya konması oldukça açık bir olgu olarak konumlandırmaktadır. Yani Lipset için demokrasinin, Batı Avrupa'da ortaya çıkan ve özünde benzersiz olduğunu ifade ettiği siyasi, sosyal, kültürel ve özellikle de ekonomik dinamiklerin bir ürünü olduğunu söylemek yanlış olmaz.

Bu noktada Lipset'in çerçevesini oluşturduğu modernleşme teorisinin çekirdeği konumundaki argümanına göre demokrasi kapitalizm temelinde şekillenen ve kapitalizmin mümkün kıldığ ürünü ya da bir sonucu olarak görülmekte ve kapitalizmin de adeta demokrasiyi meydana getiren çerçeveyi oluşturan refah, endüstrileşme, şehirleşme ve eğitim faktörlerinin bir ön şartı haline gelmektedir. Yani Lipset'e göre ekonomik anlamda geri kalmış ülkeler yeterince gelişmeleri halinde demokratikleşmeleri oldukça muhtemeldir.

\section{Modernleşme Teorisini Benimseyen Yaklaşımlar}

Lipset'in çerçevesini oluşturduğu ve bir önceki bölümde değerlendirilen "modernleşme teorisi" demokrasi ve ekonomik gelişme arasında kurduğu paradigma ile demokrasi ve demokratikleşme üzerine çalışan birçok bilim insanı tarafından benimsenerek, bu alanlarda yapılan çalışmalarda hala demokrasiyi meydana getiren dinamikler bağlamında önemli bir argüman ya da daha doğru bir ifade ile önemli bir açıklama olarak yer bulmaya devam etmektedir. 
Demokrasi ve demokratikleşme alanlarında yaptığı çalışmalarla oldukça önemli bir yere sahip olan Samuel P. Huntington (1991), dünya genelinde demokrasinin yayılmasını ve otoriter rejimlerin demokrasiye geçiş süreçlerini ele aldığı ve tartıştığ “Demokrasinin Üçüncü Dalgası” (Democracy's Third Wave) başlıklı makalesinde, Lipset'in modernleşme teorisini açıç̧a benimseyerek, demokrasi ile ekonomik gelişmişlik arasındaki bağın, diğer sosyal, ekonomik ve siyasi faktörlere kıyasla çok daha güçlü olduğunu dile getirmektedir. Lipset gibi Huntington da refah seviyesi en yüksek olan ülkelerin en demokratik ülkeler, en demokratik ülkelerin de aynı zamanda refah seviyeleri en yüksek ülkeler olduğunu ileri sürmektedir (Huntington, 1991, s.30). Huntington'a göre orta seviyede ekonomik gelişim gösteren ülkelerde demokrasiye geçiş muhtemel hale gelirken, ekonomik seviyesi düşük ülkelerde bu ihtimal düşmekle beraber, ekonomik anlamdaki bu geri kalmışlık kendisini demokratikleşme önünde bir engel olarak göstermektedir (a.g.e, s.31). Huntington, bu bağlamda Lipset'in modernleşme teorisinden yola çıkarak, Afrika'daki ülkelerin ekonomik geri kalmışlık sebebiyle, Orta Doğu ülkelerinin ekonomik geri kalmışlığın yanı sıra din temelli kültürel farklılıklar sebebiyle, Çin'in ise hem siyasi hem ekonomik hem de kültürel sebeplerden dolayı demokratikleşemediği tezini savunmaktadır (a.g.e, s.33).

Demokrasi ve demokratikleşme süreçleri hakkında karşılaştırmalı siyaset alanında yaptığı çalışmalarla tanınan Adam Przeworski ve Fernando Limongi (1997), "Modernleşme: Teoriler ve Gerçekler" (Modernization: Theories and Facts) başlıklı çalışmalarında demokrasilerin ekonomik gelişmenin bir sonucu olarak ortaya çıkıp çıkmadığı, bu kapsamda Avrupa'daki durumun kendine has özel bir vaka olup olmadığı; ya da az gelişmiş ülkelerde de gerekli ekonomik gelişme sağlandığında Avrupa'da yaşanan demokratikleşme sürecinin tekrar edip etmeyeceği gibi sorulara cevap bulmayı amaçlamaktadırlar. (Przeworksi ve Limongi, 1997, s.155). Przeworksi ve Limongi'ye göre her ne kadar bir ülkede demokrasinin ortaya çıkması için ekonomik gelişmeye birinci derecede ihtiyaç duyulmasa da, ekonomik gelişmenin yaşandığ ülkelerde demokrasilerin, ekonomik olarak daha az gelişmiş ülkelere kıyasla daha güçlü olduğunu tespit etmişlerdir. Dolayısıyla Lipset' in modernizasyon teorisi ile uyumlu bir sonuca varmışlardır (a.g.e, s.177). Przeworksi ve Limongi ayrıca ekonomik 
anlamda yaşanan gelişmenin fakir ülkelerde doğrudan demokrasiyi olmasa da demokrasiyi meydana getiren dinamiklerin ortaya çıkmasına katkı sağladığını da dile getirmektedir (a.g.e, s.177-178).

Lipset'in modernleşme teorisinin çekirdeğini oluşturan ekonomik gelişme ve demokrasi arasındaki doğrusal ilişkiyi “Demokrasi ve Ekonomik Kalkınma" (Democracy and Economic Development) başlıklı makalesinde ekonomik gelişmenin siyasal rejimlerin ortaya çıkışına ve devam etmesine olan etkisi üzerinden ele alan Przeworski (2004), aynı zamanda siyasal rejimlerin ekonomik gelişme performansına olan etkisini de sorgulamaktadır (Przeworski, 2004, s.2). Przeworski'ye göre ekonomik anlamda gelişmemiş ülkelerde de demokrasi meydana gelebilir ama bu tür ülkeler demokratikleşse bile yaşanan ekonomik sorunlar demokratik rejimleri oldukça zayıflatmakta ve istikrarsızlaştırmaktayken, ekonomik anlamda gelişmiş ülkelerdeki demokratik rejimler hem daha iyi işlemekte hem de daha istikrarlı ve sağlam olmaktadır (a.g.e, s.20). Bu noktada siyasal rejimlerin ülkelerin genel gelirlerine etkisi olmadığını tespit eden Przeworski, aynı zamanda demokrasilerin gelişmemiş ülkelerde yatırım oranlarını düşürdüğü yargısının da doğru olmadığını savunmaktadır. Çünkü Przeworski ekonomik anlamda gelişmemiş ülkelerde ülkeyi idare eden iktidarın seçimlerle gelmiş olmasının ya da yönetimin güç yoluyla ele geçirmiş olmasının ekonomik gelişme noktasında çok büyük bir fark yaratmadığını iddia etmektedir (a.g.e, s.21).

Uk Heo ve Alexander C. Tan (2001), Lipset'in modernleşme teorisi içinde ele aldığı demokrasi ve ekonomik gelişme arasındaki ilişkiyi, Przeworski'nin çalışmasına benzer bir şekilde yaptıkları ampirik çalışma çerçevesinde değerlendirerek, bu noktada hem ekonomik gelişmenin demokrasiye olan etkisini, hem de Lipset'ten farklı olarak demokrasinin ekonomik gelişmeye olan etkisini karş1lıklı olarak incelemektedirler (Heo ve Tan, 2001, s.465). Heo ve Tan, yaptıkları araştırmanın sonuçlarının Lipset'in hipotezini desteklediğini yani ekonomik gelişmenin ya da ekonomik anlamda yaşanan büyümenin demokrasiyi mümkün kıldığını ifade etmektedirler (a.g.e, s.469). Bunun yanı sıra Heo ve Tan, Lipset'in teorisinde yer vermediği bir ilişkiyi, yani demokrasinin ekonomik gelişmeye olan etkisini de bu bağlamda yaptıkları ampirik çalışma çerçevesinde değerlendirerek, aynı ekonomik gelişmenin demokrasiyi ve demokratikleşmeyi artırdığı gibi demokrasinin de ekonomik gelişmeyi artıran bir etki 
gösterdiğini savunmaktadırlar (a.g.e, s.469). Bu açıdan baktığımızda hangi değişkenin bağımlı hangisini bağımsız olduğu tartışma yaratsa da Heo ve Tan da Lipset'i kısmen doğrulayan bir analiz sunduğu söylenebilir.

Lipset'in modernleşme teorisi, özellikle ekonomik gelişme ile demokrasi ve demokratikleşme arasında kurduğu doğrusal ilişki yoluyla bu alanda yapılan çalışmalar içinde farklı soruların sorulmasına ve bu ilişkinin farklı açılardan irdelenmesine de sebep olmuştur. Bu şekilde oluşan farklı perspektiflere verilebilecek en güzel örneklerden birisinin José Antonio Cheibub ve James R. Vreeland'ın (2012), “Ekonomik Kalkınma, Demokratikleşme ve Demokrasi" (Economic Development, Democratization and Democracy) başlıklı çalışması olduğu söylenebilir. Cheibub ve Vreeland bu çalışmada Lipset'in teorisi çerçevesinde ortaya koyduğu iddiadan yola çıarak, ekonomik gelişme ve demokrasi arasındaki korelasyonun gerçek olup olmadığını, bir nedensellik içerip içermediğini ve bu ilişkinin olumlu mu olumsuz mu olduğunu sorgulamaktadır (Cheibub ve Vreeland, 2012, s.1). Cheibub ve Vreeland'a göre Lipset'in ekonomik gelişme ile demokrasi ve demokratikleşme süreçleri arasında kurduğu doğrusal ilişki kendisini açık bir şekilde ortaya koymaktadır. Cheibub ve Vreeland, özellikle ekonomik gelişmenin bir ülkedeki demokrasinin varlığını sürdürebilmesi noktasında da oldukça önemli olduğunu vurgulamaktadır (a.g.e, s.29).

Cheibub ve Vreeland, Lipset'ten farklı olarak ekonomik gelişmenin beraberinde demokratikleşmeyi getirmek zorunda olmadığını yani bu önermenin içerdiği nedenselliğin genelleştirilmesinin doğru olmadığını savunmaktadırlar. Ama bu noktada Cheibub ve Vreeland, yüksek ekonomik gelişme sağlamış ülkelerin mevcut demokrasilerini muhafaza ederek, gelecekte de demokratik kalma ihtimallerinin arttığına dikkat çekmektedir. Fakat ekonomik anlamda yeterince gelişmemiş ülkelerin ise demokratik olmalarına rağmen, demokratik rejimin değişerek ya da devrilerek, otoriter bir rejimin ortaya çıkma ihtimalinin yüksek olduğunu savunmaktadir (a.g.e, s.30).

Ronald Inglehart ve Christian Welzel (2005), modernleşme teorisi çerçevesinde demokrasi ile birlikte irdelenen değişim süreçlerini ve bu değişimleri meydana getiren dinamikleri ele aldıkları “Modernleşme, Kültürel 
Değişim ve Demokrasi" (Modernization, Cultural Change and Democracy) isimli çalışmalarında, Lipset'e oldukça yakın bir bakış açısı benimsemektedirler (Ingelhart ve Welzel, 2005, s.15-18). Ingelhart ve Welzel için modernleşme olgusu genel anlamda siyasi, sosyal, ekonomik ve kültürel değişimlerin kesiştiği ve birbirlerini farklı açılardan etkileyerek çok boyutlu değişimlere yol açtığ 1 dönüşüm süreçlerinin oluşturduğu bir bütünlüktür. Bundan dolayı Ingelhart ve Welzel, Lipset'ten farklı olarak sadece ekonomik gelişme üzerinden değil, aynı zamanda sosyal temelli süreçleri de dahil ederek oluşturdukları "sosyo-ekonomik" gelişim olgusunun değişimi getirdiğini savunmaktadırlar (a.g.e, s.15). Lipset'in hipotezine paralel olarak Ingelhart ve Welzel de sosyo-ekonomik gelişimin demokrasinin ortaya çıkmasını etkilediğini belirtmekle birlikte yine Lipset'in iddia ettiği gibi ekonomik anlamda yaşanan sorunların demokrasinin yerini otoriter bir rejime bırakması gibi sonuçlara yol açabildiğini öne sürmektedir (a.g.e, s.20).

Daron Acemoğlu ve James A. Robinson (2005), Lipset' in ekonomik gelişme ve demokrasi arasındaki doğrusal ilişki üzerinden oluşturduğu hipotezindeki varsayıma benzer bir şekilde, demokrasinin yanı sıra diktatörlüklerin ekonomik kökenlerini sorguladıkları "Diktatörlügün ve Demokrasinin Ekonomik Temelleri" (Economik Origins of Dictatorship and Democracy) isimli kitaplarında, demokrasinin ortaya çıkması, konsolide olması ve varlığını sürdürmesi gibi fenomenleri açıklayacak bir konsept oluşturmaya çalışmaktadırlar. Bu bağlamda Acemoğlu ve Robinson Lipset gibi temelde ekonomik gelişme ile siyasal rejimler arasında doğrusal bir ilişkinin varlığını kabul etmektedir. Bu kapsamda 1960 ve 2000 yılları arasında ekonomik anlamda belli bir gelişme seviyesine ulaşmış ülkelerin tamamının hem demokratik olduğunu hem de demokrasinin bu ülkelerde oldukça istikrarlı bir şekilde devam ettiğini tespit etmektedirler (Acemoglu ve Robinson, 2005, s.68).

Acemoğlu ve Robinson bu tespitten yola çıkarak, Lipset'in de iddia ettiği gibi ekonomik gelişimin siyasal değişimi beraberinde getirdiğini ve bu yolla birçok ülkenin demokratikleştiği tezini savunmalarına rağmen, Lipset'in bunu sürekli tekrar eden ve neredeyse hep aynı şekilde tezahür eden bir mekanizmaya dönüştürdüğü iddiasının aksine bu tür bir ekonomik gelişmenin otoriter rejimlerin ortaya çıkma ihtimalini tamamen orta- 
dan kaldırmadığını savunmaktadırlar (a.g.e, s.80-83). Acemoğlu ve Robinson bu farklılığa rağmen Lipset'in tespit ettiği ekonomik gelişme ve demokrasi arasındaki korelasyonun ampirik verilerle de ortaya konulabilen bir gerçeklik olduğunu ve bundan dolayı da en önemli "siyasal ekonomik" gerçeklerden birisi olarak kabul edilmesi gerektiğini dile getirmektedirler (a.g.e, s.318).

Demokrasi ve demokratikleşme gibi konular hakkında yaptığı çalışmalarla taninan Dietrich Rueschemeyer, Evelyn H. Stephens ve John D. Stephens (1991), "Kapitalist Kalkınma ve Demokrasi" (Capitalist Development and Democracy) başlıklı kitaplarında demokrasiyi ortaya çıkaran ve istikrarlı bir şekilde devam etmesini sağlayan dinamikleri kapitalist ekonominin etkileri üzerinden ele almaktadırlar. Bu noktada Rueschemeyer, Stephens ve Stephens' in öne çıkardıkları en önemli olgu ise, Lipset'in modernleşme teorisi kapsamında ekonomik gelişme ve demokrasi arasında var olduğunu savunduğu doğrusal ilişkiye paralel olarak kapitalist ekonominin meydana getirdiği toplumsal değişimlerin uzun vadede demokratik bir rejimin oluşmasını mümkün kıldığı varsayımıdır (Rueschemeyer vd., 1991, s.1). Bu varsayımı demokrasinin Batı dünyasının endüstrileşmiş kapitalist toplumlarında ortaya çıkmış olduğu gerçeği üzerinden temellendiren Rueschemeyer, Stephens ve Stephens, endüstrileşen ve kapitalist ekonomiyi benimseyen Batı Avrupa ülkelerinde ortaya çıkan "işçi sınıfının" siyasal hayata dahil olarak meydana getirdikleri etkinin demokrasiyi mümkün kıldığını savunmaktadırlar. (Rueschemeyer vd. 1992, s.243). Dolayısıyla Rueschemeyer, Stephens ve Stephens de aynı Lipset gibi ekonomik gelişme ve demokrasi arasında doğrusal bir bağ olduğunu ve bu bağın ülkeler arasında yapılan karşılaştırmalar sonucunda elde edilen ampirik verilerle de doğrulanabilir olduğunu belirterek, kapitalist gelişme ile demokrasi arasındaki korelasyonun kabul edilmesi gereken bir sonuç olduğunu dile getirmektedir (Rueschemeyer vd. 1991, s.4).

Yukarıda ele alınan çalışmaların temel ortak noktası Lipset'in 1950'ler sonunda ortaya attığı demokrasi ve ekonomik gelişme arasındaki doğrusal ilişki tezini benimsemeleridir. Bu açıdan bakıldığında modernleşme yaklaşımının değişime uğramasına rağmen demokrasi ve demokratikleşme literatüründe belirgin konumunu koruduğunu iddia etmek çok da yanlış olmaz. 


\section{Modernleşme Teorisini Eleştiren Yaklaşımlar}

Lipset'in demokrasiyi meydana getiren dinamiklerin temellerini oluşturan ve ülkelerin demokratikleşmesini sağlayan bir katalizör olarak gördüğü ve bu fenomenleri açılamak amaciyla oluşturduğu teorinin temeli içinde konumlandırdığı ekonomik gelişme ile demokrasi ve demokratikleşme arasındaki doğrusal ilişki, aynı zamanda bu tür bir varsayımı eleştiren birçok yaklaşımı da beraberinde getirmiştir.

Barrington Moore (1966), ekonomik anlamda yaşanan gelişmelerin tarım toplumlarını endüstrileşmiş modern toplumlara dönüştürmesi ile ortaya çıkan siyasal dönüşümleri, Lipset'in hipotezindeki mekanik ilişkiyi sorgulayan bir yaklaşımla, ekonomik gelişmelerin meydana geldiği toplumları dönüştürdügüüü ve yaşanan bu dönüşümün farklı rotalar oluşturarak birbirinden farklı siyasal rejimlerin oluşmasını sağladığını savunmaktadır (Moore, 1966, s.11). Moore'a göre yaşanan ekonomik gelişimler toplumun sahip olduğu sınıfsal yapıyı değiştirmekte ve bu değişimin ortaya çıkardığı yeni sınıfsal dinamikler de siyasal rejimleri belirleyen en önemli faktör konumuna oturmaktadır (a.g.e, s.413). Moore, ekonomik gelişmeler sonucunda değişen toplumsal yapı içindeki sınıfların İngiltere, Fransa ve ABD'de kapitalist-demokrasiyi meydana getirdiğini, bu değişimin Almanya ve Japonya'da daha otoriter bir karaktere sahip kapitalistreaksiyoner bir rejimi mümkün kıldığını ileri sürmüştür. Diğer taraftan Moore Çin ve Rusya' da ise değişen toplumsal sınıfların komünizm temelli rejimleri ortaya çıkardığını savunmaktadır (a.g.e, s.418).

Demokrasi ve demokratikleşme üzerine özellikle Güney Amerika ülkeleri hakkında yaptığı çalışmalarla tanınan Guillermo O'Donnell (1973) "Modernleşme ve Bürokratik Otoriteryanizm: Güney Amerika Siyaseti Üzerine Çalışmalar" (Modernization and Bureaucratic-Authoritarianism: Studies in South American Politics) başlıklı kitabında Lipset'in ekonomik gelişme ve demokrasi arasındaki doğrusal olduğunu iddia ettiği ilişkiye eleştirel bir şekilde yaklaşmakta ve 1960 ve 1970 yılları arasında Arjantin, Brezilya ve Uruguay gibi o dönemde büyük ekonomik gelişme gösteren ülkeleri analiz etmektedir (O'Donnell, 1973, s.10-12). Lipset'in, bir ülke ne kadar ekonomik gelişim gösterirse, o ülkede demokrasinin ortaya çıma ihtimalinin ya da mevcut demokrasinin istikrarlı bir şekilde devam etme- 
sinin ihtimalinin arttığı öngörüsünü eleştiren O’Donnell, ekonomik gelişme yoluyla ortaya çıkan sosyal ve siyasal değişimlerin yönünün farklı olabileceğini belirterek, bu şekilde bir genelleme yapmanın yanlış olabileceğini çünkü ekonomik gelişme gösteren bir ülkenin otoriterleşme ihtimalinin hala devam ettiğini ve ekonomik anlamda daha az gelişmiş bir ülkenin de demokratik rejimini sürdürebileceğini savunmaktadır (a.g.e, s.4-8). O’Donnell incelediği Güney Amerika ülkelerinde ekonomik gelişmenin otoriterliğin bir türü olarak tanımladığı "bürokratik otoriteryanizmi" meydana getirdiğini belirterek, özellikle Arjantin'de 1966 yılında yaşanan darbenin ülkede yaşanan ekonomik gelişmenin meydana getirdiği siyasi, sosyal ve kurumsal değişimlerin bir sonucu olarak konumlandırmaktadır (a.g.e, s.199). Bu noktada O'Donnell ele aldığı Arjantin, Brezilya ve Uruguay'daki ekonomik gelişmelere rağmen yaşanan siyasal istikrarsızlık ve askeri darbelerin Lipset'in tezini yanlışladığını öne sürmektedir. Diğer bir deyişle, Güney Amerika örneğinin sosyo-ekonomik gelişmenin demokrasiyi beraberinde getirdiğini varsayan bir mekanizma olarak görülemeyeceğini gösterdiğini ileri sürmektedir (a.g.e, s.204).

Adam Przeworski, otoriter rejimlerden demokrasiye geçişi mümkün kılan dinamikleri ve faktörleri ele aldığ “ "Demokrasiye Geçiş Çalışmalarının Bazı Sorunları" (Some Problems in the Study of the Transition to Democracy) başlıklı makalesinde, demokrasiye geçişin özünde birbirinden bağımsız ama birbirine paralel gelişen otoriter bir rejimin liberalleşme yoluyla tasfiyesi ve demokratik kurumların meydana gelmesi olmak üzere tanımladığı iki ana sürecin meydana gelmesi ile mümkün olduğun ifade etmektedir (Przeworski, 1991, s.56). Bu noktada Przeworski, Lipset'in ekonomik gelişim ile demokrasi arasındaki doğrusal ilişkinin bir sonucu olarak kabul ettiği kapitalist demokrasinin temelde sermaye sahipleri ile maaşlı çalışanlar yani işçiler arasındaki dengeye dayandığını belirtmektedir.

Przeworski, bu bağlamda Lipset'ten farklı olarak yaşanan ekonomik gelişmenin boyutundan ziyade, sermaye sahipleri ile işçiler arasındaki gelir dağılımı noktasındaki sorunların giderilmesi ile ortaya çıan bu dengenin hem demokratikleşme hem de demokrasinin devamı için daha önemli ve belirleyici bir unsur olduğunu savunmaktadır (a.g.e, s.61-62). Bu dengenin sağlanamadığı durumlarda ise siyasal rejimin ortaya çıkacak krizler yoluyla istikrarsızlaşacağını dile getiren Przeworski, Belçika, Fransa, İsveç ve İngiltere'de demokrasinin sermaye sahipleri ve çalışanlar 
arasındaki dengenin demokratik bir koalisyon temelinde sağlanması ile daha sabit bir hale geldiğini belirtir. Dolayısıyla Przeworski demokrasiye geçişin sadece ekonomik gelişimle ya da üretimin artırılmasıyla değil, aynı zamanda gelir dağılımı ile oldukça yakından ilişkili olduğunu tespit etmektedir (a.g.e, s.63).

Ekonomik gelişme temelli gelir artışından ziyade eşit gelir dağılımının demokratikleşme konusunda daha belirleyici bir faktör olduğu konusunda Przeworski ile aynı pozisyonu paylaşan Julian Wucherpfennig ve Franziska Deutsch da Lipset'in ekonomik gelişmenin demokrasinin ortaya çıkışındaki olumlu etkisini ve rolü üzerinden oluşturduğu nedenselliği sorgulamaktadırlar (Wucherpfennig ve Deutsch, 2009, s.1-2). Bu bağlamda ekonomik gelişme ve demokrasinin ortaya çıkışı arasındaki doğrusal ilişkiyi demokratik bir rejimin sağlamlığ 1 ve o rejimi meydana getiren mekanizma üzerinden inceleyen Wucherpfennig ve Deutsch, sosyo-ekonomik gelişmenin demokrasiyi meydana getirmesi noktasında Lipset'in temel aldığı gelir artışı faktörünün bu tür bir nedenselliği ortaya koymadığını öne sürmektedirler. Buna bağlı olarak demokrasinin ortaya çıkışının sadece artan gelirle ortaya konulamayacağını ve gelir dağılımı eşitliğinin demokrasinin ortaya çıkmasında çok daha belirleyici bir faktör olarak görülmesi gerektiğini savunmaktadır (a.g.e, s.4).

Ronald Inglehart ve Christian Welzel (2010), modernleşme teorisinin ekonomik anlamda yaşanan gelişmelerin toplum ve siyaset içinde sistematik değişimlere neden olduğu varsayımından yola çıarak, Lipset'in ekonomik gelişme ve demokrasi arasında kurduğu doğrusal ilişkiyi "Kitlelerin Değişen Öncelikleri: Modernleşme ve Demokrasi arasındaki İlişki" (Changing Mass Priorities: The Link between Modernization and Democracy) başlıklı çalışmalarında birçok farklı açıdan ele almıştır. Daha önce bahsi geçen çalışmalarında Lipset'in ekonomik kalkınma yaklaşımını sosyo-ekonomik kalkınma olarak okuyan Inglehart ve Welzel (2005), Lipset'i takip eden bir anlayış benimsemiştir. Fakat daha sonra bu çalışmalarını revize etmiş ve modernleşmenin düzlemsel olmadığını vurgulayan bir yaklaşım benimsemişlerdir (Ingelhart ve Welzel, 2010, s.552). Ingelhart ve Welzel'e göre "endüstrileşme"; bürokratikleşme, hiyerarşinin oluşması, otoritenin merkezileşmesi, sekülerleşme ve geleneksel değerlerden seküler-rasyonel değerlere geçiş gibi birçok olguyu meydana getiren en önemli dinamiklerin başında gelmektedir (a.g.e, s.552). Endüstrileşen 
toplumlarda ortaya çıkan kişisel otonomi ve kendini ifade etme gibi değerler otoriter rejimleri zayıflatırken demokratik rejimlerin ortaya çıkma ihtimalini yükseltmektedir. Bu noktada Lipset'in Batı dünyası merkezli demokrasi anlayışını eleştiren Ingelhart ve Welzel, demokratikleşmenin "batılılaşma" anlamına gelmediğini, özellikle de Doğu Asya ülkelerinin son yıllarda oldukça büyük ekonomik gelişmeler kaydederek, bu varsayımı ortadan kaldırdığını öne sürmektedirler (a.g.e, s.552). Tüm bunları göz önünde bulunduran Ingelhart ve Welzel, özellikle endüstrileşme yoluyla ortaya çıkan gelişmelerin demokrasinin yanı sıra aynı zamanda faşizmi, komünizmi, teokrasiyi de aynı şekilde ortaya çıkarabileceğini dile getirmektedir (a.g.e, s.552-553).

Renske Doorenspleet (2004), demokrasiye geçişi mümkün kılan ekonomik gelişme, ekonomik büyüme ve ülkelerin dünya sistemi içindeki rolü gibi yapısal faktörleri ele almıştır. "Güncel Demokrasiye Geçişlerin Yap1sal Arka Planı" (The structural context of recent transitions to democracy) başlıklı makalesinde, Lipset' in demokrasinin ortaya çıkması ya da demokrasiye geçişte bir olmazsa olmaz haline getirdiği ekonomik gelişme ve demokrasi arasında kurduğu doğrusal ilişkinin varlı̆̆ının kabul görmüş bir gerçek olduğunu ifade etmektedir (Doorenspleet, 2004, s.312). Fakat bu noktada Huntington'ın demokrasinin dünya genelinde yayılışını açıklamak amacıyla oluşturduğu üç dalganın devamı olarak kabul gören ve 1989 yılı itibariyle başlayan dördüncü dalga içinde aralarında ekonomik gelişmenin de bulunduğu yapısal faktörleri ampirik olarak ele alarak, değerlendirmelerde bulunan Doorenspleet, Lipset'in ekonomik gelişmenin demokrasinin ortaya çıkışında olumlu bir rol ve etkisi olduğu varsayımının 1989'dan itibaren geçerliliğini kaybettiğini belirtir. Çünkü bu dönemde ekonomik olarak gelişmemiş ülkelerin demokrasiye geçiş yaptığ1 gözlemlenirken, ekonomik anlamda daha gelişmiş ülkelerde demokratik olmayan rejimlerin devam ettiği tespit edilmektedir (a.g.e, s.324-326).

Doorenspleet, bu bağlamda rejimlerin geçirdiği değişimler içindeki dinamikleri, Lipset'in öngörüsünün aksine yaşanan ekonomik gelişmelere rağmen demokratikleşmeyi beraberinde getirmediği gibi aksine demokratikleşme süreçlerini de olumsuz etkileyebileceğini savunmaktadır (a.g.e, s.326). Doorenspleet, bu noktada özellikle politik liderler ile onları destekleyen gruplar arasındaki ilişkinin, rejim değişikliği yani demokrasiye geçiş noktasında ekonomik gelişmelerden daha önemli olduğunun 
altını çizerek, ekonomik gelişmelerin bu iki grup arasındaki ilişkiye etki eden ve istikrarlı kılan bir unsur olarak öne çıtığını savunmaktadır (a.g.e, s.326).

\section{Sonuç}

Lipset, 1959 yılında yayınladığı "Some Social Requisites of Democracy: Economic Development and Political Legitimacy" başlıklı makalesi içinde modernleşmeyi ve modernleşmenin etkisi ile ortaya çıkan gelişmelerin sonuçlarını ekonomik temellere ilişkilendirerek, bu şekilde ortaya çıkan ekonomik gelişmelerin siyasi, sosyal ve kültürel yansımaları üzerinden bir analiz düzlemi oluşturmaktadır ve bu özelliğiyle de halen karşılaştırmalı siyaset literatüründeki etkisini sürdürmektedir.

Modernleşmenin bir sonucu olarak ortaya çıkan ekonomik gelişme ve bu gelişmenin yarattığı etkilerle değişen toplumların demokrasiye doğru bir eğilim göstermesi olgusu Lipset için Batı temelli bir fenomene dönüşmektedir. Her ne kadar Lipset bu konuda herhangi bir vurguda bulunmasa da, ekonomik gelişmenin bir sonucu olarak demokrasinin ortaya ç1kışı Lipset'in konsepti içinde Batı merkezli bir fenomene dönüşerek, modernleşme ve demokratikleşme süreçleri de dolaylı olarak bir "Batıl1laşma" sürecine doğru evrilmektedir. Bu açıdan bakıldığında da Lipset'in demokrasi ve ekonomik kalkınma arasında kurduğu ilişki Türkiye örneği için de önem arzetmektedir. Cumhuriyetin kuruluşundan bu yana Batıl1laşmayı hedefleyen Türk demokrasisinin dalgalanmalarını ekonomik dalgalanmaları ile ilişkilendirmek yanlış olmaz. Diğer taraftan bugün yaşanılan demokrasi krizlerini sadece ekonomik kalkınma kaynaklı açıklamak yetersiz kalmaktadir.

Bu kapsamda Lipset'e yöneltilen eleştirilerin başında Batı Avrupa ülkelerinde yaşanan siyasi, sosyal, ekonomik ve kültürel değişimlerin sonucunda ortaya çıkan demokrasi olgusunun, diğer toplumlar için de geçerli kılınabilecek ve şartlar sağlandığında aynı Batı Avrupa'da olduğu gibi kendini mekanik olarak tekrar edecek bir sürecin sonucu olmadığı gelmektedir. Bu noktada yöneltilen eleştirilerin ortak noktası modernleşme süreçlerinin Lipset'in iddialarının aksine doğrusal olmadığı, yani hep aynı 
yöne doğru ilerleyen ve benzer sonuçlar üreten bir süreçler zinciri olmadığıdır. Yani modernleşme beraberinde demokrasiyi getirebildiği gibi otoriter rejimlerin ortaya çımasına da sebep olabilmektedir.

Sonuç olarak Lipset, ekonomik gelişmişlik ve demokrasinin ortaya ç1kışı arasında kurduğu doğrusal ilişki demokrasi ve demokratikleşme literatürünü derinden etkilemiştir. Bu açıdan hem benzer perspektifte birçok çalışmanın yapılmasına vesile olmuş, hem de eleştirilerek demokrasinin bir ülke veya bir toplum içinde meydana gelişini farklı şekilde açıklayan yaklaşımların ortaya çıkmasına da dolaylı olarak katkıda bulunmuştur. Genel anlamda Lipset'in modernleşme teorisinin ortaya çıtığ 1959 yılından günümüze kadar uzanan bir süreç içinde birçok açıdan değişen dünya konjonktürü göz önünde bulundurulduğunda, geçerliliğini kaybettiğini söylemek yanlış olmaz. Ama yine de demokrasi bağlamında örnek olarak gösterilen ülkelerin, Lipset'in teorik çerçevesinde de belirttiği şekilde demokratikleşmiş olmaları ise hala geçerliliğini korumaktadır. 
EXTENDED ABSTRACT

\title{
Rethinking Modernization Theory: A Critical Perspective on The Relationship Between Economic Development and Democracy
}

\author{
Şebnem Yardımcı Geyikçi - Uğur Çil \\ Hacettepe University
}

In the 1960s modernization theory has become one of the dominant paradigms in sociology and political science and both disciplines relied on it in explaining why non-Western countries remained underdeveloped. Modernization theory, which suggests that economic development requires a cultural and social transformation, has also affected the literature on comparative politics, particularly when democracy has become the dominant regime type in the Western world. As such, many studies to date has employed this approach as a way to understand and explain the processes of democratization in different contexts. Seymour Martin Lipset, the founding father of modernization theory, approaches democratization as a natural outcome of modernization and forms a linear relationship between the economic development and the social and political development. Modernization theory argues that democratization involves a transformation from an agrarian, feudal and traditional society into a capitalist, industrialized, and rationalized society which is organized within the framework of a nation-state. The theory assumes that modernization automatically involves this transformation and each and every society which follows the path of modernization will experience these changes one way or another.

Lipset's article "Some Social Requisites of Democracy: Economic Development and Political Legitimacy" published in 1959 is considered to be a seminal work in this respect. Lipset argues that there is a correlation between economic development and democracy in that the higher the level of economic development and economic welfare the higher the chances of 
democracy to survive. The major goal of this article is to rethink the premises of modernization theory based on the aforementioned article of Seymour Martin Lipset from the perspective of comparative politics. As such, in this article we critically analyzed the theories of democratization based on the modernization approach and try to observe the impact of modernization theory on the democratization literature.

Accordingly, we looked at many different studies from varied perspectives which based their arguments on modernization theory. Some of these works confirm Lipset's claim while others challenge and ask to rethink his premises. We argue that Lipset's claim still occupies a central place in democratization studies. The link he formed between economic development and democracy has been analyzed by many different works in the scholarship in that this relationship has been verified both qualitatively and quantitatively which led to continuous applicability of his work. Even the ones who challenged and criticized Lipset's linear approach to modernization such as Przeworski (2004), Cheibub and Vreeland (2012), Ingelhart and Welzel (2005) have suggested that the most advanced democracies in the world are also the ones which are economically well developed. In other words, the very fact that the most advanced democracies enjoy developed economies makes Lipset's link between democracy and economic development a widely accepted approach.

Conversely, one of the major challenges to Lipset's approach has asserted that the emergence of democracy in the Western Europe resulted from a political, social, economic and cultural transformation might not repeat itself in other contexts mechanically even when non-Western societies experience similar transformations. Accordingly, the major criticism argues that contrary to what Lipset suggests, the modernization path is not a linear one which produces same outcomes everywhere. These transformations not always bring about democracy but in some cases it might even lead to the emergence of authoritarian regimes. In this respect, the work of O'Donnell (1973) is particularly noteworthy who suggests that economic development in Latin America had played a key role in the emergence of authoritarian regimes.

Overall, we argue that modernization theory as offered by Lipset which assumes a strong link between economic development and democracy has influenced the literature on democratization significantly. As 
such, this approach has triggered many follow-up studies that either embrace or challenge the linear relationship between economic development and democracy. We might even suggest that modernization theory itself has affected the emergence of alternative modernization theories. Here, it is also important to acknowledge that the developments the world has experienced since 1959 when Lipset's article was first published have shown that modernization theory suffers from significant flaws and it is one of the most criticized theories in the discipline of political science. However, this does not change the fact that Lipset's argument still enjoys a certain validity since it is still the case that the most advanced democracies are also the ones with highest economic development which makes it a particularly interesting approach in understanding the processes of democratization.

To sum up, this article aims to critically look at the democratization literature based on the modernization theory. In doing so, we first provide a discussion on the concepts of democracy and democratization as studied in comparative politics. Then, we discuss the Lipset's article in detail and offer different studies which followed the footsteps of Lipset and tested his claim. Following that, we analyzed the critical perspectives on the link between economic development and democracy. Finally, we provide a discussion on the strengths and weakness of these works that either adapted or criticized Lipset.

\section{Kaynakça / References}

Acemoglu, D. ve Robinson, J. A, (2005). Economic origins of dictatorship and democracy. New York: Cambridge University Press.

Altun, F. (2002), Modernleşme kuramı: Eleştirel bir giriş. İstanbul: Yöneliş Yayınevi.

Bowles, S. ve Gintis, H. (1996). Demokrasi ve kapitalizm: Mülkiyet, cemaat ve modern toplumsal düşüncenin çelişkileri. İstanbul: Ayrıntı Yayınevi.

Cheibub, J., A. ve Vreeland, J., R. (2012). Economic development, democratization and democracy, 23.12.2018 tarihinde https://www.uio.no/english/research/interfaculty-research-areas/democracy/newsand-events/events/conferences/2012/papers-2012/Cheibub-Vreeland-Wshop7.pdf adresinden erişildi. 
Diamond, L. (1999). Developing democracy: Toward consolidation. Baltimore: JHU Press.

Doorenspleet, R. (2004). The structural context of recent transitions to democracy, European Journal of Political Research, 43, 309-335.

Feldman, A., S. ve Hurn, C. (1966). The experience of modernization, American Sociological Association, 29 (4), 378-395.

Geddes, B. (1999). What do we know about democratization after twenty years?, Annual Review of Political Science, 2(1), 115-144.

Goorha, P. (2010). Modernization theory,In Oxford Research Encyclopedia of International Studies (1-22), New York: Oxford University Press.

Gürsoy, Y. (2016). Rejim değişiklikleri: Otoriterleşme ve demokratikleşme. (S. Sayarı ve H. D. Bilgin, Der.), Karşılaştırmalı Siyaset: Temel Konular ve Yaklaşımlar içinde (75-100), İstanbul: İstanbul Bilgi Üniversitesi Yayınları.

Heo, U. ve Tan, A., C. (2001). Democracy and economic growth: A causal analysis, Comparative Politics, 33 (4), 463-473.

Huntington, S., P. (1991). Democracy's third wave, Journal of Democracy, 2 (2), 12-34.

Inglehart, R. ve Welzel, C. (2005). Modernization, cultural change, and democracy: The human development sequence. New York: Cambridge University Press.

Inglehart, R. ve Welzel, C. (2010). Changing mass priorities: The link between modernization and democracy, Reflections, 8 (2), 551-567.

Jan, D. (2006). Einführung in die vergleichende politikwissenschaft. Wiesbaden: VS Verlag.

Lipset, S., M. (1959). Requisites of democracy: Economic Development and political legitimacy, The American Political Science Review, 53 (1), 69105.

Lipset, S., M. (1969). Political man. Sussex: Heinemann Educational Books.

Lipset, S., M. (1994). The social requisites of democracy revisited: 1993 presidential address, American Sociological Review, 59 (1), 1-22.

Miller, M., K. (2012). Economic development, violent leader removal, and democratization, American Journal of Political Science, 56 (4), 10021020.

Moore, B., (1966). Social origins of dictatorship and democracy: Lord and peasant in the making of the modern world. Boston: Beacon Press. 
Newton, K. ve Van Deth, J., W. (2014). Karşılaştırmalı siyasetin temelleri. Ankara: Phoenix Yaymevi.

O'Donnell, G., A., (1973). Modernization and bureaucratic-authoritarianism: Studies in South American politics, University of California, Berkeley: Institute for International Studies.

Pennock, J., R. (1979). Democratic political theory. New Jersey: Princeton University Press.

Przeworski, A. (1991). Some problems in the study of the transition to democracy, (O’Donnell, P. C. Schmitter ve L. Whitehead Der.). Transitions From Authoritarian Rule. Comparative Perspectives. Baltimore: John Hopkins University Press.

Przeworski, A. (2004). Democracy and economic development. (E. D. Mansfield, ve R. Sisson Der.). Democracy, Autonomy, and Conflict in Comparative and International Politics. Columbus: Ohio State University Press.

Przeworski, A. ve Limongi, F. (1997). Modernization: Theories and facts, World Politics, 49 (2), 155-183.

Rueschemeyer, D., Stephens, E. H., Stephens, J. D. (1991). Capitalist development and democracy. Chicago: University of Chicago Press.

Rueschemeyer, D., Stephens, J., D., Huber, E. (1992). Capitalist development and democracy, Contemporary Sociology, 72 (3), 243-248.

Schoeder, R. (1998). Max Weber, democracy and modernization. London: MacMillan Press.

Schumpeter, J., A. (2003). Capitalism, socialism and democracy. London: Routledge.

Sözen, Y. (2016). Siyasi rejimler: Demokrasiler ve diğer sistemler. (S. Sayarı, ve H. D. Bilgin, Der.). Karşılaştırmalı Siyaset: Temel Konular ve Yaklaşımlar. İstanbul: İstanbul Bilgi Üniversitesi Yayınları.

Tilly, C. (2014). Demokrasi, (E. Arıcan çev.). İstanbul: Phoenix Yayınevi.

Tipps, D., C. (1973). Modernization Theory and the Comparative Study of Societies: A Critical Perspective, Comparative Studies in Society and History, 15 (2), 199-226.

Weber, M. (1946). Sociology in essays. New York: Oxford University Press.

Wucherpfennig, J. ve Deutsch, F. (2009). Modernization and democracy: theories and evidence revisited, Living Reviews in Democracy, 1, 19 . 


\section{Kaynakça Bilgisi / Citation Information}

Yardımcı-Geyikçi, Ş. ve Çil, U. (2019). Modernleşme teorisini yeniden düşünmek: Ekonomik kalkınma ve demokrasi ilişkisine eleştirel bir bakış. OPUS-Uluslararası Toplum Araştırmaları Dergisi, 11(18), 2996-3022. DOI: 10.26466/opus.561066 